(RESEARCH ARTICLE)

\title{
Epidemiological study of Enterogyrus melenensis, stomach parasitic helminth of Hemichromis fasciatus in the Mefou hydrographic system (South-Cameroon, Africa); effect of the environment
}

\author{
Nack Jacques ${ }^{1,}{ }^{*}$, Mbondo Jonathan Armel ${ }^{2}$, Bassock Bayiha Etienne Didier ${ }^{3}$ and Bilong Bilong Charles \\ Félix ${ }^{3}$
}

${ }^{1}$ University of Douala, Faculty of Science, PO Box 24157, Douala, Cameroon.

${ }^{2}$ Specialized Research Center for Marine Ecosystems, IRAD, PO. Box 219, Kribi, Cameroon.

${ }^{3}$ Laboratory of Parasitology and Ecology, Faculty of Science, University of Yaounde I, P.O Box 812, Cameroon.

Publication history: Received on 23 July 2020; revised on 03 August 2020; accepted on 06 August 2020

Article DOI: https://doi.org/10.30574/wjarr.2020.7.2.0275

\begin{abstract}
Hemichromis fasciatus is a voracious predator and a prolific breeder used to control Tilapia reproduction. Parasitic diseases can affect growth, reproduction and many other parameters of the dynamics of host populations. The present study aimed to compare the infection dynamics of E. melenesis between three ecosystems. Fish were sampled from December 2017 to September 2019 using a gill net, they were euthanized and the parasitological examination was carried out within 24 hours after capture. The abdominal cavity was opened; the sex were identified, then the digestive tract was removed and; the stomach isolated. Monogeneans were dislodged from the stomach wall and mounted in a drop of ammonium picrate-glycerine mixture. Their identification was based on the morphology of sclerotized parts of the haptor and male copulatory organ. Of 302 host specimens examined, 152 were infected by 2590 Enterogyrus melenensis. The overall mean intensity was low and did not vary significantly between the three ecosystems studied, while the prevalence globally differed significantly. The mean intensity and prevalence of E. melenensis varied with seasons but were not cyclic. The inner location of E. melenensis attenuates the direct influence of the water temperature on this endohelminth resulting in its non-cyclical profile. This study highlights the necessity to consider the environment when comparing host parasitism; it also reinforces the practice recommending quarantining native large fish specimens captured in the nature and used as sires in ponds, in order to avoid epizootic outbreaks.
\end{abstract}

Keywords: Monogenean; Infection; Sex; Length; Season

\section{Introduction}

Cichlids fishes commonly named Tilapia are important aquaculture organisms in the world they have been introduced to at least 140 countries and have turned into worldwide invasive fishes [1]. Hemichromis fasciatus (Peters, 1858) has been used or studied for use in Africanaquaculture; amongst others it is a voracious predator and a prolific breeder used to control Tilapia reproduction [2, 3]. Parasitic diseases can affect growth, reproduction and many other parameters of the dynamics of natural host populations $[4,5,6,7]$. These hazards can be devastating for both farming systems and natural populations due to stressful conditions linked to food and frequent deterioration in water quality $[8,9,10]$.

In Cameroon, $H$. fasciatus is currently parasitized by the Monogenean species Enterogyrus melenensis located in the stomach of host individuals [11]. Monogeneans are mainly ectohelminths but some species are endoparasites s.l. and have unusual locations $[12,13,14]$, for example: the oesophagus for Diplectanotrema Johnston and Tiegs, 1922, urinary bladder and ureters for and Allison, 1940 and Urogyrus cichlidarum Bilong Bilong, Birgi and Euzet, 1994, nasal cavity for Dactylogyrus nasalis Strelkov and KhaKi, 1964, ovipositor for Dactylogyrus sp. Yukhimenko and Danilov, 1987 and stomach for Enterogyrus (Paperna, 1963).The specific morphology of the haptor of Enterogyrus spp. and their mode of

\footnotetext{
${ }^{*}$ Corresponding author: Nack Jacques
} 
attachment provoke lesions on the gastric epithelium of their hosts and may cause pathological conditions $[15,16]$. Due to the relative abundance of $H$. fasciatus in previous fish catches and the fact that it is also highly consumed in our town personal observations, the present study aimed to compare the infection dynamics of E. melenensis between three ecosystems.

\section{Material and methods}

\subsection{Study sites}

This study was conducted around Yaounde, on the southern plateau of Cameroon characterized by a bimodal humid tropical rainfall regime with four seasons: a long dry season (LDS) from mid-November to mid-march, a short rainy season (SRS) from mid-march to June, a short dry season (SDS) from July to august, and a long rainy season (LRS) from September to mid-November [17]. The annual rainfall is $1650 \mathrm{~mm}$ with peaks in May (196 mm) and October (293 $\mathrm{mm})$, minimum values in January $(30 \mathrm{~mm})$ and July $(37 \mathrm{~mm})$; the atmospheric mean temperature is $23.5{ }^{\circ} \mathrm{C}$ and the hygrometry $80 \%$ [18]. Three different ecosystems where considered in the Mefou hydrographic system : the Mefou dam in the Ozum village $\left(11^{\circ} 27^{\prime} \mathrm{N} ; 3^{\circ} 40^{\prime} \mathrm{E}\right)$ in the upstream course, Obili $\left(3^{\circ} 51^{\prime} \mathrm{N} ; 11^{\circ} 29^{\prime} \mathrm{E}\right)$ a private semi- intensive pond in the middle course, and two tributaries in the forest downstream course [(Ezazock $\left(11^{\circ} 32^{\prime} \mathrm{N} ; 3^{\circ} 40^{\prime} \mathrm{E}\right)$ and Ekali $\left.\left(11^{\circ} 32^{\prime} \mathrm{N} ; 3^{\circ} 38^{\prime} \mathrm{E}\right)\right]$.These localities were visited for fishing at least twice a month; no sampling was done in the SDS 2018 due to infrastructural and logistic shortages.

\subsection{Host sampling and parasitological examination}

Fish were sampled from December 2017 to September 2019 using a gill net and transported to the laboratory in isothermal tanks. In the laboratory, they were euthanized; a spike was introduced into the brain of the fish which was then disrupted by the rotary movement of the spike [19]. The parasitological examination was carried out within 24 hours after fish capture. The Standard length [(SL), horizontal distance from front tip of snout to base (articulation) of caudal fin [20] was measured to the nearest millimeter $(\mathrm{mm})$ using a Carbon fiber Calliper. The abdominal cavity was opened using a medio-sagittal section. The fish sexes were determined (as male, female or undetermined), then the digestive tract was removed; the stomach was isolated and placed in a Petri dish containing a wet filter paper. The remaining parts of the digestive tract were fixed in a $10 \%$ formalin solution for subsequent studies. Monogeneans were searched under a stereomicroscope then dislodged from the stomach wall using a dissecting needle. Parasites were then mounted on a microscope slide in a drop of ammonium picrate-glycerine mixture according to [21]; the preparation was covered with a cover slip and sealed with Glyceel according to [22]. Worms were identified based on the morphology of sclerotized parts of the haptor and male copulatory organ according to [11], using a Leica DM2500 microscope equipped with a Leica DFC425 camera.

\subsection{Data analysis}

Data measurements were log transformed to satisfy homoscedasticity or linearity necessary to perform parametric tests [23]. Abundance, intensity, mean intensity, prevalence, xenopopulation and infrapopulation were defined according to [24]. Multiple comparisons of mean intensities were tested using variance analysis (ANOVA). Student's ttest was used to compare mean intensities between male and female. The Tukey's post-hoctest was used to compare helminth loads between two seasons andecosystems. The Chi-square $(\chi 2)$ test made it possible to compare prevalence. The Sperman's coefficient " $r_{s}$ " was used to investigate the correlation between abundance of parasites and hosts' standard length. These analyses were performed using the software PAST.16 and Quantitative Parasitology 3.0 All values of $\mathrm{P}<5 \%$ were considered significant.

\section{Results}

\subsection{Dynamics of Enterogyrus melenensis in three ecosystems of the Mefou Hydrographic system}

A total of 302 Hemichromis fasciatus specimens were examined; their standard length (SL) ranged from 20 to $81 \mathrm{~mm}$. 2590 Enterogyrus melenensis individuals were collected from the stomach; this species presented an aggregate distribution $\left(\mathrm{s}^{2} / \mathrm{Im}>1\right)$. Among the total host, $150 \mathrm{H}$. fasciatus revealed uninfected. The mean intensity was low (17.04) and did not vary significantly between the three ecosystems studied $(\mathrm{F}=0.88 ; \mathrm{P}=0.5)$. On the contrary, the prevalence globally differed significantly $\left(\chi^{2}=110.3, \mathrm{P}=1.15^{\mathrm{E}-32}\right)$ and varied between the pond (lower) and Mefou dam $\left(\mathrm{P}=2.6^{\mathrm{E}-32}\right)$, the pond and forest downstream course $\left(\mathrm{P}=1.4^{\mathrm{E}-19}\right)$, Mefou dam (higher) and forest downstream course $(\mathrm{P}=0.006)$ see table 1. 
Table 1 Prevalence, mean intensity, and aggregation of Enterogyrus melenensis, stomach parasite of $H$. fasciatus in three ecosystems of the Mefou hydrographic system.

\begin{tabular}{llllll}
\hline Ecosystems & Fish examined & Fish parasitized & Prevalence (\%) & MI \pm SE & Aggregation (s2/MI) \\
\hline PO & 101 & 2 & 2 & $22 \pm 21$ & 42.01 \\
MD & 123 & 100 & 81.3 & $15.61 \pm 1.3$ & 15.11 \\
FD & 78 & 50 & 64.1 & $19.7 \pm 2.42$ & 21.9 \\
\hline \multicolumn{4}{r}{} & SE= Standard Error; P0= pond; MD= Mefou dam; FD= forest downstream course; MI = mean intensity
\end{tabular}

\subsection{Relationship between intensity of E. melenensis and the host standard length}

In the overall host sample, the intensity of E. melenensis slightly decreased significantly $(\mathrm{P}=0.045)$ as the length of $H$. fasciatus increased $(\mathrm{r}=-0.11)$. This decrease of the intensity was more apparent in the MD ecosystem $(\mathrm{r}=-0.34 ; \mathrm{P}=$ 0.0001; see Fig.1) while in the FD ecosystem, the intensity was positively linked to the $\mathrm{LS}\left(\mathrm{r}=0.44 ; \mathrm{P}=4.3^{\mathrm{E}-05}\right.$, see Fig.2). No relationship was found between the intensity and LS in the PO (Pond).

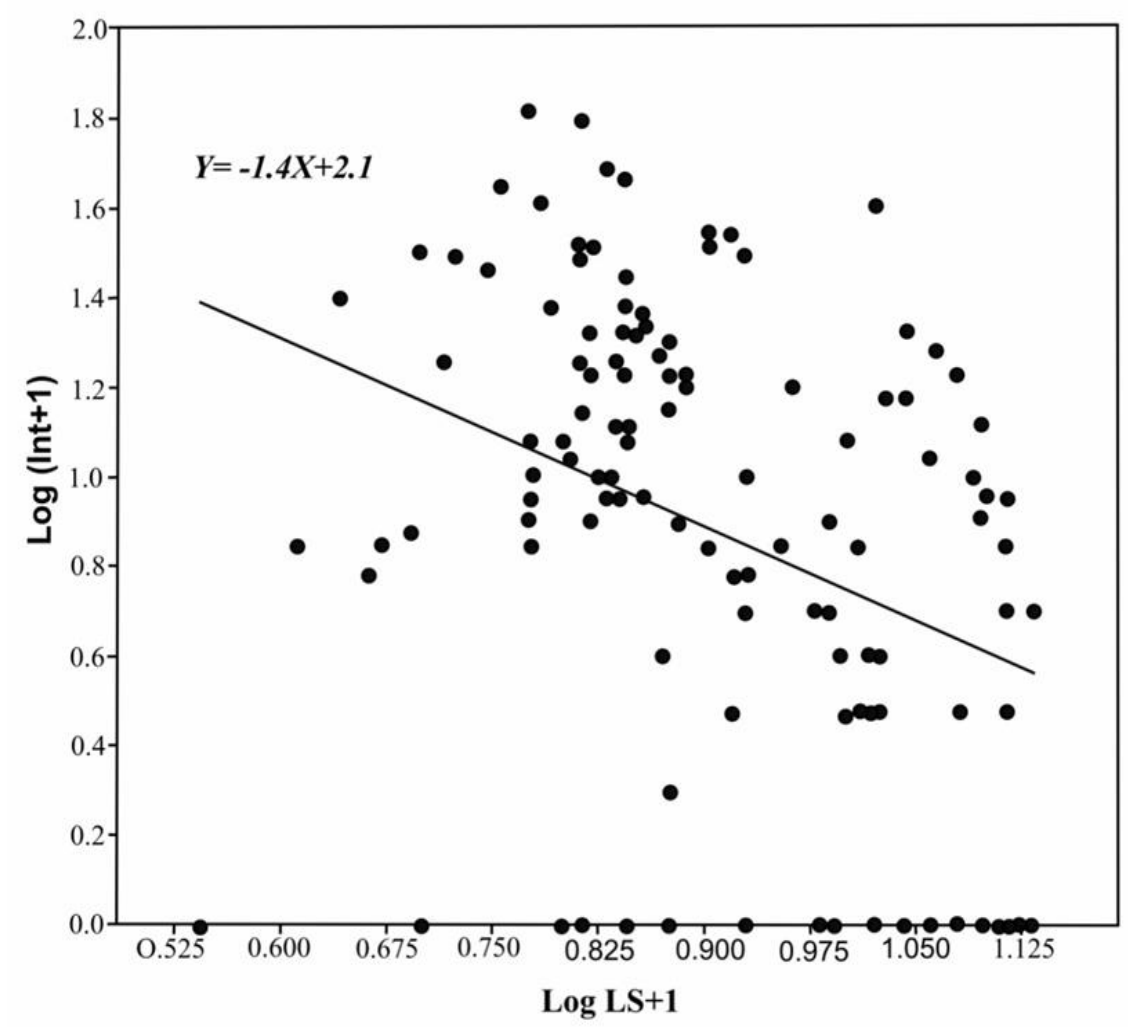

Figure 1 Regression curve between E. melenensis intensity and H. fasciatus Standard Length in the Mefou dam 


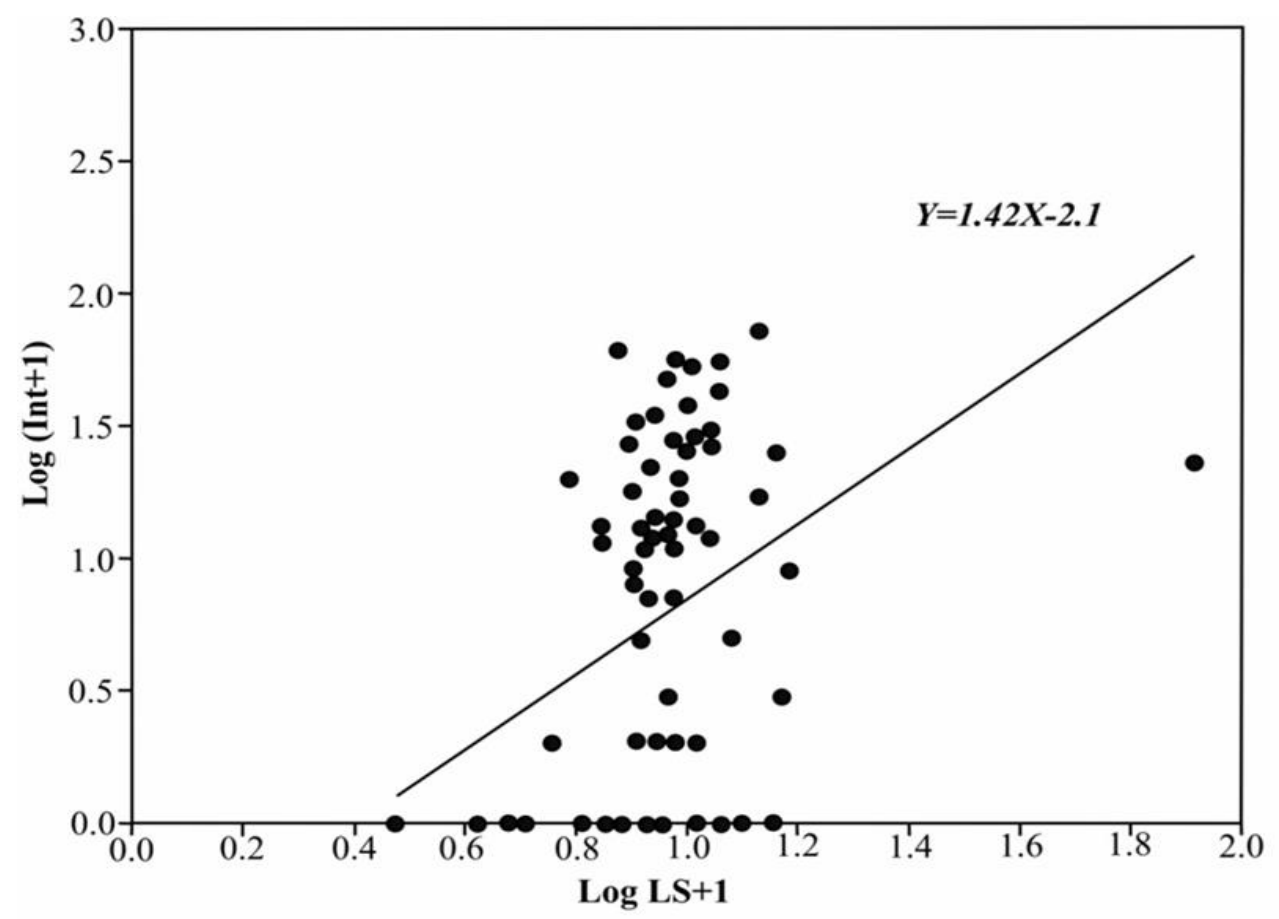

Figure 2 Regression curve between E. melenensis intensity and H. fasciatusStandard Length in the Forest downstream course

\subsection{RelationshipbetweenE. melenensisbetween the intensity and host sex}

Among the total host sample (302 H. fasciatus), the sex of 277 individuals was determined. The intensity and the prevalence of E. melenensis were not sex dependent (table 2).

Table 2 Prevalence and mean intensity of E. melenensis as a function of the host sex

\begin{tabular}{lllll}
\hline Sex & Number examined & Number infected & Prevalence (\%) & MI \pm SE \\
\hline Males & 123 & 67 & 54.4 & $16.79 \pm 1.79$ \\
Females & 154 & 80 & 51.9 & $16.9 \pm 1.76$ \\
Statistics - & & $\chi 2=0.13 ; \mathrm{P}=0.67$ & $\mathrm{t}=0.05 ; \mathrm{P}=0.95$ \\
\hline \multicolumn{5}{r}{$\mathrm{MI}=$ mean intensity }
\end{tabular}

\subsection{Seasonal variation of the parasitism byE. melenensis}

Enterogyrus melenensis parasitized its host population during all the sampling periods (table 3).

Table 3 Prevalence and mean intensity of E. melenensis as a function of the seasons

\begin{tabular}{llll}
\hline Seasons & Fish examined & Prevalence (\%) & MI \pm SE \\
\hline LDS 2017 & 44 & 47 & $4.9 \pm 0.37$ \\
SRS 2018 & 11 & 45 & $21 \pm 10.5$ \\
LRS 2018 & 20 & 90 & $13.4 \pm 3.09$ \\
LDS 2018 & 63 & 57 & $20.3 \pm 2.6$ \\
SRS 2019 & 75 & 48 & $16.8 \pm 2.47$ \\
SDS2019 & 45 & 33 & $15.4 \pm 3.19$ \\
\hline
\end{tabular}


Both epidemiological indexes (mean intensity and prevalence) varied with seasons, but without an obvious profile, and were not cyclic.

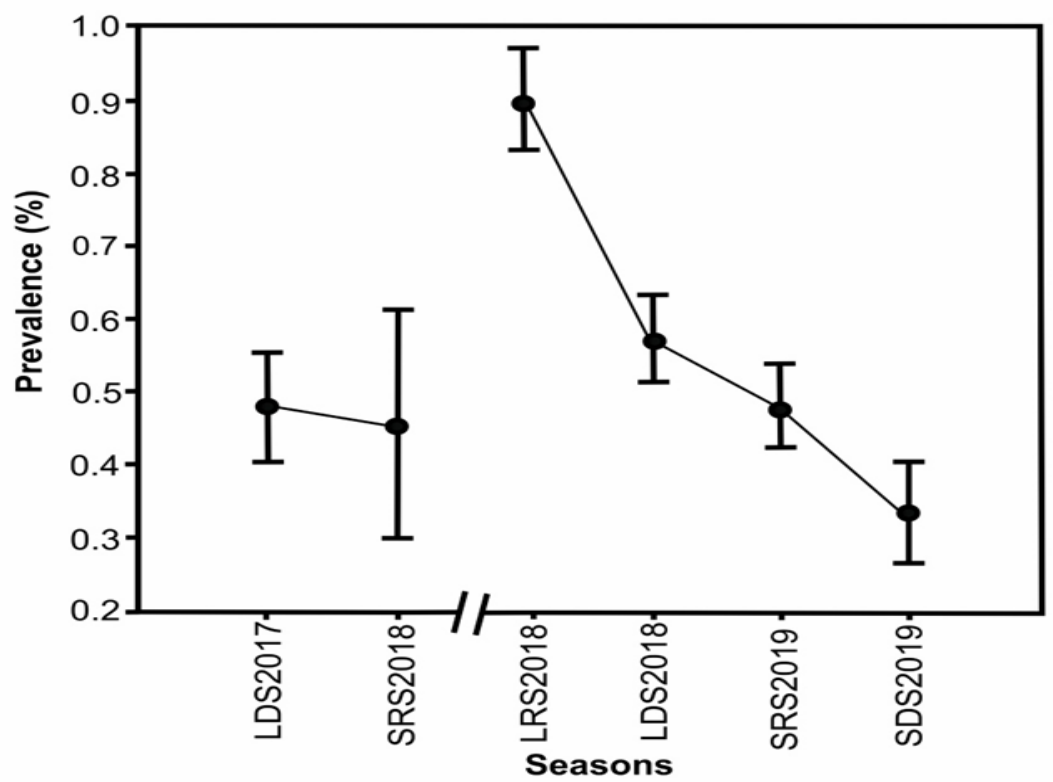

Figure 3 Seasonal variation of prevalence of E. melenensis

For a given season, the values of these indexes significantly differed, from one year to another (table 3; Fig.3 and Fig.4)

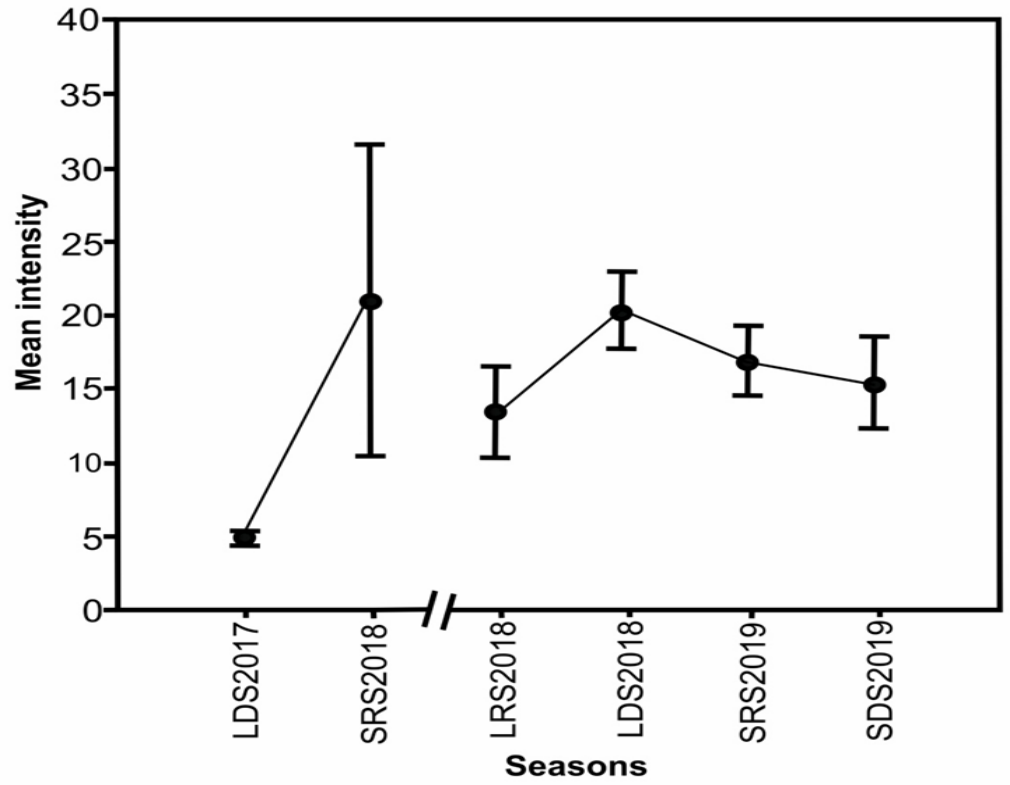

Figure 4 Seasonal variation of the intensity of E. melenensis

Differences in intensities between seasons were significant: SRS2018 and LDS2017 (K=4.38; P=0.02), LDS2018 and LDS2017 (K=4.21; $\mathrm{P}=0.03)$ (Table 4).

For the prevalences, significant differences were noted between: LDS2017 and LRS2018 $\left(\chi^{2}=7.25\right.$; $\left.=0.001\right)$; SRS2018 and LRS2018 ( $\left.\chi^{2}=4.1 ; \mathrm{P}=0.008\right) ; \operatorname{LRS} 2018$ and LDS2018 ( $\left.\chi^{2}=4.8 ; \mathrm{P}=0.001\right) ; \operatorname{LRS} 2018$ and SRS2019 $\left(\chi^{2}=8.26 ; \mathrm{P}=0.001\right)$; LRS2018 and SDS2019 ( $\left.\chi^{2}=13.14 ; \mathrm{P}=0.001\right)$ (Table 4). 
Table 4 Multiple comparisons of seasonal intensities (A) and prevalences (B) of E. melenensis

\begin{tabular}{|c|c|c|c|c|c|c|}
\hline LDS2017 & & $0.01 ; 0.90$ & $7.25 ; 0.001 *$ & $0.68 ; 0.34$ & $0.00 ; 0.97$ & $1.36 ; 0.17$ \\
\hline SRS2018 & $4.38 ; 0.02^{*}$ & & $4.1 ; 0.008 *$ & $0.37 ; 0.48$ & $0.01 ; 0.88$ & $0.38 ; 0.46$ \\
\hline LRS2018 & $2.32 ; 0.56$ & $2.05 ; 0.69$ & & $4.8 ; 0.001 *$ & $8.26 ; 0.001 *$ & $13.14 ; 0.001 *$ \\
\hline LDS2018 & $4.21 ; 0.03^{\star}$ & $0.17 ; 1$ & $1.88 ; 0.76$ & & $0.85 ; 0.28$ & $4.4 ; 0.015$ \\
\hline SRS2019 & $3.25 ; 0.19$ & $1.12 ; 0.96$ & $0.93 ; 0.98$ & $0.95 ; 0.98$ & & $1.8 ; 0.11$ \\
\hline \multirow[t]{2}{*}{ SDS2019 } & $2.85 ; 0.32$ & $1.52 ; 0.89$ & $0.53 ; 0.99$ & $1.35 ; 0.99$ & $0.39 ; 0.99$ & \\
\hline & LDS2017 & SRS2018 & LRS2018 & LDS2018 & SRS2019 & SDS2019 \\
\hline
\end{tabular}

\section{Discussion}

The present study deals with the dynamics of E. melenensis, a stomach parasite of $H$. fasciatus from three ecosystems in the Mefou hydrographic system.This monogenean was aggregated within the host population. Most of the host individuals carried a small proportion of parasites, while a small number of fish carried a larger proportion of parasites. This distribution pattern agrees with [25] who stated that in most cases, parasites are almost universally aggregated between their hosts. According to [26] the aggregative distribution may indicate heterogeneity in the relationship between the host and the parasite populations. This distribution pattern could be advantageous for the parasite insofar as it increases the opportunities for mating [27].

The mean intensity of E. melenensis in the three ecosystems was always low $(10<\mathrm{IM} \leq 50)$ according to the categorization of parasitism in our environment [28]. High prevalence was observed both in the Mefou dam and forest zone of the Mefou. Only 2 fish individuals out of 101 from the pond were parasitized. It is suggested that regular pond emptying, which eliminates part of the infecting larvae (oncomiracidia) and eggs of the parasite, and fishing may reduce the xenopopulation of this endoparasite. As far as ectoparasitic monogeneans are concerned, according to [29] the degree of infection depends on the condition and density of the hosts; according to [30] the strong water current is also often a factor limiting the invasion of such infective larva stages thus reducing the intensity of parasitism. Therefore the reduced or low water current in the Mefou dam, and the apparent higher host density favor the higher prevalence observed, compared to the forest downstream course where the water current is more rapid, fish more scattered and therefore their density apparently lower.

Globally the intensity of E. melenensis slightly decreased as the length of the host increased, although in the forest ecosystem, we found the inverse effect. This contrary result seems unintelligible concerning the same host/parasite and hydrographic systems. Many investigations on the relationship between the intensity of ectoparasitic monogeneans and the size (or age) of the host exist. Most authors found that the intensity of monogeneans increased with fish standard length [31, 32, 30,33]; this result is always explained by the fact that larger fish offer large surface areas for parasites to colonize [31, 34], [35, 36]. Infrequently, it is stated that the intensity of monogeneans decreases as the host size (or age) increases [37]. In this case, according to [38] the host immunity to explain such result, according to [39] this result is attributed to the self-cure mechanism triggered by the increase of the parasite population. We suggest that the reduction of an infrapopulation by the process of acquired immunity in large host [37] or the self-cure mechanism [39] is preceded by the parasite accumulation in a host up to a certain threshold which stimulates its defense. This last phenomenon could explain the positive correlation between the intensity and the host size in the forest downstream course. Moreover, according to also [36] the relationship between the number of endoparasites and host size is less clear compared that to with ectoparasites. But in general, acquired immunity tends to induce convex changes in mean worm load with host age where the peak levels of infection occur in younger hosts. 
The prevalence and the mean intensity of E. melenensis were not host sex dependent. The same observation was obtained for ectoparasitic monogeneans of Oreochromis niloticus [40, 41].According to [13] the sedentary lifestyle of $H$. fasciatus individuals of both sexes during the spawning period justifies the equal level of infestation between males and females. This explanation is palatable in the case of Enterogyrus melenensis also transmitted directly by a free infective larva (oncomiracidium).

Enterogyrus melenensis parasitized its host population throughout the year with seasonal variations but without a clear profile. In the same climatic zone, clear seasonal profiles have been defined for ectoparasitic monogeneans of $H$. fasciatus[13],Barbus martorelli[42]. In both cases and over consecutive years, the prevalence and intensity of the ectohelminths were highest during the rainy seasons, lowest in dry seasons especially in LRS. In this study, the infection level was not cyclical. The water temperature is always assumed to be an important factor in controlling the occurrence of ectoparasitic monogeneans [43]. Although fish are ectotherms, E. melenensis being an endoparasite s.l., it is suggested that its inner location attenuates the direct influence/effect of the water temperature on the metabolism of this helminth, resulting in the non-cyclical profile observed.

\section{Conclusion}

It emerges from this study that a high prevalence of E. melenensis was observed in the Mefou dam and in the forest zone of this river hydrographic system, the values being higher in the dam where the water current is reduced and the host density apparently higher. Well managed, pond emptying could be an optimal strategy to diminish monogenean infective larval loads preventing epizootic events. The gathering of parasites, over time, in $H$. fasciatus specimens could stimulate the host defense (immunity) to lessen the worm load (intensity). The inner location of E. melenensis attenuates the direct influence of the water temperature on this endohelminth resulting in its non-cyclical profile.This study also highlights the necessity to consider the environment when comparing host parasitism. These findings reinforce the practice recommending quarantining native large fish specimens captured in the nature and used as sires in ponds, in order to avoid epizootic outbreaks.

\section{Compliance with ethical standards}

\section{Acknowledgments}

The study was funded by the special research allowances from higher education from Cameroon and internal allowances from University of Douala and University of Yaounde I.

\section{Disclosure of conflict of interest}

The authors declares no conflict of interest.

\section{References}

[1] Deines AM, Wittmann ME, Deines JM and Lodge DM. (2016). Tradeoffs among ecosystem services associated with global Tilapia introductions. Reviews in Fisheries Sciences and Aquaculture, 24(2), 178-191.

[2] Balarin JD andHatton JP. (1979).Tilapia: A guide to their biology \& culture in Africa. University of Stirling, Scotland, 175.

[3] Jackson PBN. (1988).Aquaculture in Africa. In C.Lévêque M.N. Bruton G.W. Ssentongo (Eds), Biology and Ecology of African Freshwater Fishes.l'ORSTOM, 508.

[4] Hudson PJ andDobson AP. (1989).Population biology of Trichostrongylus tenuis, a parasite of economic importance forred grouse management. Parasitology Today, 5, 283-291.

[5] Begon M, Bowers RG, Radianakis N and Hodgkinson DE. (1992). Diseases and community structure: the importance of host self-regulation in a host pathogen model. American Nature, 139(6), 1131-1150.

[6] Simkova A, Gelnar M andSasal P. (2001). Aggregation of congeneric parasites (Monogenea: Dactylogyrus) among gill microhabitats within one host species (Rutilus rutilus). Parasitology, 123, 599-607.

[7] BakkeTA, Harris PD andCable J. (2002). Host specificity dynamics: Observation on gyrodactylidmonogeneans. International Journal for Parasitology, 32, 281-308.

[8] Michel C. (1989).Pathology of Tilapias. Aquatic Living Resources, 2, 117-126. 
Nack J et al. / World Journal of Advanced Research and Reviews, 2020, 07(02), 025-033

[9] Meyer FP. (1991).Aquaculture disease and health management. Jounal of Animal Science, 69, 4201-4208.

[10] Bondad-Reantaso MG, Subasinghe RP, Arthur JR, Ogawa K, Chinabut S, Adlard R, Tan Z and Shariff M.(2005). Disease and health management in Asian aquaculture. Veterinary Parasitology, 132(3-4), 249-272.

[11] Bilong Bilong CF, Birgi E and Lambert AW. (1989). Enterogyrus melenensis n. sp. (Monogenea, Ancyrocephalidae), parasite stomacal de Hemichromis fasciatus Peters, 1857 (Téléostéen, Cichlidae) du Sud-Cameroun. Revue de Zoologie Africaine, 103, 99-105.

[12] Rohde K. (1993).Ecologie of Marine parasite: An Introduction to Marine Parasitology. 2nd Edition CAB International, 198.

[13] Bilong Bilong CF. (1995). Les Monogènes parasites des poissonsd'eaudouce du Cameroun biodiversité et spécificité; biologie des populations inféodées à Hemichromis fasciatus. (DOCTORAT d'Etat). Université de Yaounde I, Cameroun, 341.

[14] Cassier P, Brugerolle G, Combes C, Grain J and Raibaut A. (1998).Le parasitisme, un équilibre dynamique. Masson Edition, 366.

[15] Pariselle A, Lambert A and Euzet L. (1991). A new type of haptor in mesoparasitic monogeneans of the genus EnterogyrusPaperna, 1963, with a description of Enterogyrusforatusn.sp.and E. coronatus n.sp., stomach parasites of Cichlids in West Africa. Systematic Parasitology, 20, 211-220.

[16] Zhang S, Zhi T, Xu X, Zhen Y, Bilong Bilong CF, Pariselle A and Yang, T.(2019). Monogenean fauna of alien Tilapias (Cichlidae) in South China.Parasite, 26, 1-16.

[17] Suchel JB. (1987). Les climats du Cameroun. (Thèse de Doctoratd'Etat). Université de Bordeaux III, 1186.

[18] Olivry JC. (1986). Fleuves et rivières du Cameroun. Monographies Hydrologiques ORSTOM. Paris, MESRESORSTOM, 781.

[19] Scholz T, Rehulkova E and Kuchta R. (2018).Guide to the Parasites of African Freshwater Fishes. In. ScholzT,Vanhove MPM, SmitN, Jayasundera Z \&Gelnar M. (Eds).Parasitological of Fish (Dissection), 65-69.

[20] Stiassny MLJ, Teugels GG and Hopkins CD. (2007). Poissons d'eaux et saumâtres de basse Guinée, ouest de l'Afrique centrale. Volume I. IRD, MnHn, MRAC, Paris, 800.

[21] Malmberg G. (1957).On the occurrence of Gyrodactylus on Swedish fishes. Skrifterutgivnaav Södra Sveriges Fiskeriföreningen, 1956, 19-76.

[22] Bates JW. (1997).The slide-sealing compound “Glyceel”. Journal of Nematology, 29(4), 565-566.

[23] Terbraa K CJF and Smilauer P. (1998).Canoco reference manual and user's pakage to Canoco for windows: software for canonical community ordination (version 4). Ithaca, New York, Microcomputer Power.

[24] Bush AO, Lattery KD, Lotz JM and Shostak AW. (1997). Parasitology meets ecology on its own terms: Margolis et al. revisited. The Journal of Parasitology, 83, 575-583.

[25] Krasnov BR and Poulin R. (2010). Ecological properties of a parasite: species specific stability and geographical variation. In Morand S and Krasnov BR (Eds), The biogeography of host-parasite interactions Oxford University, New York, 99-114.

[26] Combes C, Garotti L, Moulia C andSicard M. (2018).Parasitisme, Ecologieet Evolution des interactions durables. Paris, Dunod, 332.

[27] Kennedy CR. (1977).The regulation of fish parasite populations. In G.W. Esh (Eds), Regulation of parasite populations.New York, Academic Press, 253.

[28] BilongBilong CF and Njiné T. (1998).Dynamique de populations de trois Monogènes parasites d'Hemichromis fasciatus (Peters) dans le lac Municipal de Yaoundé etintérêt possible en pisciculture intensive. Sciences Naturelles et Vie, 34(2), 295-303.

[29] ErgensR. (1983).A survey of the results of studies on Gyrodactylus katharineri Malmberg, 1964 (Gyrodactylidae: Monogenea). Folia Parasitologyca, 30(4), 319-327.

[30] Silan P and Maillard C. (1986).Structure spatiale et temporelle des populations naturelles d'helminthes parasites de poissons: le modèle Bar-Diplectanum. In: Actes du colloque national du CNRS sur la biologie des populations, 215-216. 
[31] Tombi J and Bilong Bilong CF. (2004). Distribution of gill parasites of the freshwater fish Barbus martorelli Roman, 1971 (Teleostei: Cyprinidae) and tendency to inverse intensity evolution between Myxosporidia and Monogenea as a function of the host age. Revue d'Elevage et de Médecine Vétérinaire des Pays Tropicaux, 57, 7176.

[32] Buchmann K. (1989). Relationship between host-size of Anguilla Anguilla and infection level of the Monogeneans Pseudodactylogyrus spp. Journal of Fish Biology, 35, 599-601.

[33] Hughes GM and Morgan M. (1973). The structure of fish gills in relation to their respiratory function. Biological Reviews of the Cambridge Philosophical Society, 48, 419-475.

[34] Cable J, Tinsley RC and Harris PD. (2002).Survival and embryo development of Gyrodactylus gasterostei (Monogenea: Gyrodactylidae). Parasitology, 124(1), 53-68.

[35] Guégan JF and Hugueny B. (1994). A nested parasite species subset pattern in tropical fish: host as major determinant of parasite infracommunity structure. Oecologia, 100, 184-189.

[36] Lo CM, Morand S and GalzinR. (1998). Parasite diversity/ host age and size relationship in three coral-reef fishes from French Polynesia. International Journal for Parasitology, 28(11), 1695-1708.

[37] Cloutman DG. (1978). Abundance of Cleidodiscus pricei Mueller (Monogenea: Dactylogyridae) on the flat bullhead, Ictalurus platycephalus (Girard), in Lake Norman, North Carolina. Journal of Parasitology, 64(1), 170-172.

[38] Shotter RA. (1980). Aspects of parasitology of the catfish Clarias anguillaris (L.) from a river and a lake at Zaria, Kaduna State, Nigeria. Bulletin de l'Institut Français d'Afrique Noire, 42 (4A), 836-859.

[39] Paperna I. (1979). Monogenea of Inland water fish in Africa. Annales du Musée Royal de l'Afrique Centrale. Série Zoologie, 226, 1-131.

[40] TombiJ, Akoumba JF and BilongBilong CF. (2014). The monogenean community on the gills of Oreochromis niloticus from Melen fish station in Yaoundé, Cameroon. International Journal of Modern Biological Research, 2 , 16-23.

[41] Boungou M, Kabré G, Marques A and SawadogoL. (2008). Dynamics of population of five parasitic Monogeneans of Oreochromis niloticus Linné, 1757 in the dam of Loumbila and possible interest in intensive pisciculture. Pakistan Journal of Biological Sciences, 11(10), 1317-1323.

[42] Bilong Bilong CFand Tombi J. (2005).Temporal structure of a component community gill parasites of Barbus martorelli Roman, 1971 (Freshwater Cyprinidae) in the centre province, Cameroon. Cameroon Journal of Biological and Biochemical Sciences, 13(1), 9-18.

[43] Simkova A, Morand S, Matejusova I, Jurajda P and Gelnar M. (2001). Local and regional influence on patterns of parasite species richness of central European fishes. Biodiversity and conservation, 10, 511-525.

\section{How to cite this article}

Nack J, Mbondo JA, Bassock Bayiha ED and Bilong Bilong CF. (2020). Epidemiological study of Enterogyrus melenensis, stomach parasitic helminth of Hemichromis fasciatus in the Mefou hydrographic system (South-Cameroon, Africa); effect of the environment. World Journal of Advanced Research and Reviews, 7(2), 25-33. 